\title{
Implementation of Article 82 of the United Nations Convention on the Law of the Sea: the Challenge for Canada
}

\author{
Aldo Chircop
}

The United Nations Convention on the Law of the Sea, 1982 (LOSC)1 contains an obscure, unprecedented and unique provision in international law concerning equitable sharing of ocean resources, as follows:

Article 82

Payments and contributions with respect to the exploitation of the continental shelf beyond 200 nautical miles

1. The coastal State shall make payments or contributions in kind in respect of the exploitation of the non-living resources of the continental shelf beyond 200 nautical miles from the baselines from which the breadth of the territorial sea is measured.

2. The payments and contributions shall be made annually with respect to all production at a site after the first five years of production at that site. For the sixth year, the rate of payment or contribution shall be 1 per cent of the value or volume of production at the site. The rate shall increase by 1 per cent for each subsequent year until the twelfth year and shall remain at 7 per cent thereafter. Production does not include resources used in connection with exploitation.

3. A developing State which is a net importer of a mineral resource produced from its continental shelf is exempt from making such payments or contributions in respect of that mineral resource.

4. The payments or contributions shall be made through the Authority, which shall distribute them to States Parties to this Convention, on the basis of equitable sharing criteria, taking into account the interests and

1 United Nations Convention on the Law of the Sea, Montego Bay, 10 December 1982 (adopted 10 December 1982, entered into force 16 November 1994), 1833 UNTS 3 [hereinafter LosC]. 
needs of developing States, particularly the least developed and the landlocked among them. ${ }^{2}$

After its adoption at the Third United Nations Conference on the Law of the Sea in 1973-82 (UNCLOS III) the provision hardly received further attention. This was possibly because the prospects of technological and commercial feasibility of deep sea drilling were remote at the time and the inconvenience it entailed for domestic revenue generation regimes. It is unprecedented because it was the first provision in a multilateral treaty to introduce an international royalty on natural resource production within national jurisdiction. The discourse on equitable sharing of ocean resources was a dominant theme at UNCLOS III and in subsequent instruments of international environmental law, and currently in the discourse on the conservation of areas beyond national jurisdiction. ${ }^{3}$ Article 82 stands out in the discourse on international equity as it sets out a novel framework for equitable sharing of production from non-living resources within national jurisdiction.

The literature on the diplomatic history of Article 82 explains how this provision secured a key compromise in the UNCLOS III package deal and needs no revisit. ${ }^{4}$ Articles 82 and 76 constituted a quid pro quo. ${ }^{5}$ There would have been no agreement on key aspects of Article 76 concerning the extended continental shelf, i.e., that part of the shelf defined in the LOSC as extending beyond the limits of the exclusive economic zone (EEZ) and reaching out seaward to the outer limits of the continental margin, without a counterpart

2 Ibid, Art 82.

3 Development of an International Legally Binding Instrument under the United Nations Convention on the Law of the Sea on the Conservation and Sustainable Use of Marine Biological Diversity of Areas beyond National Jurisdiction, UN General Assembly Resolution 292 (LXIX), 19 June 2015, available at < https://documents-dds-ny.un.org/doc/UNDOC/GEN/ N15/187/55/PDF/N1518755.pdf?OpenElement>.

4 SN Nandan \& S Rosenne, vol. eds., United Nations Convention on the Law of the Sea 1982: A Commentary, Vol. 2 (Dordrecht: Nijhoff, 1993), commentary on Part VI, Article 82, at 930-947 [hereinafter Nandan \& Rosenne]; RJ Dupuy \& D Vignes, $A$ Handbook on the New Law of the Sea (The Hague: Nijhoff, 1991), 375-381; A Chircop \& B Marchand, 'International Royalty and Continental Shelf Limits: Emerging Issues for the Canadian Offshore,' (2003) 26 Dalhousie Law Journal 273 at 283-293; A Chircop, 'Operationalizing Article 82 of the United Nations Convention on the Law of the Sea: A New Role for the International Seabed Authority?' (2004) 18 Ocean Yearbook (2004) 395 at 395-412; Issues Associated with the Implementation of Article 82 of the United Nations Convention on the Law of the Sea, ISA Technical Study no. 4 (Kingston, Jamaica: International Seabed Authority, 2009) [hereinafter Chatham House Report].

5 Ibid, Nandan \& Rosenne, 932. 
agreement on the equitable sharing of non-living resources of the extended shelf. The compromise was difficult because States enjoying broad margins (known as margineers) were confronted by land-locked and geographically disadvantaged States who felt that the margineers' negotiating position was being advanced at the expense of the International Seabed Area (the Area). An earlier United Nations General Assembly resolution had declared the Area as common heritage of mankind, a unique legal status for the global commons and not susceptible to appropriation by any State. ${ }^{6}$ In the event that a natural resource deposit straddles the extended continental shelf and the Area, further issues arise in the implementation of Article 82. ${ }^{7}$

Although not a beneficiary of Article 82, the International Seabed Authority (the Authority), a new intergovernmental organization established by the LOSC, is a stakeholder of the provision because it is tasked with receiving payments and contributions in kind, developing equitable criteria for distribution to beneficiaries, and the administration of the funds. The Authority cannot perform its distributive tasks unless extended continental shelf States perform their respective responsibilities. Moreover, as the organization with the exclusive mandate for the administration of deep sea mining activities in the Area, the Authority could conceivably be engaged in dialogue with the coastal State over resource production and management of non-living resources that straddle the outer limits of the continental shelf and the Area.

Although the deep water market for offshore hydrocarbons is depressed by prolonged low oil prices, investments are still substantial and driven predominantly by expenditures in Africa and the Americas. ${ }^{8}$ There are relatively few activities in the deep waters of extended continental shelves and these include Angola, Brazil, eastern Canada, northern Norway and the United States' Gulf of Mexico. Most activities are prospecting or exploratory in nature. The United States is not a State Party to the LOSC and to date has not issued discovery licenses on the extended continental shelf. However, it was the first State to implement Article 82 in the calls to tender in the Central Gulf of Mexico, by

6 Declaration on Principles Governing the Sea-Bed and the Ocean Floor, and the Subsoil Thereof, beyond the Limits of National Jurisdiction, UN General Assembly Resolution 2749 (XXv), 17 December 1970, available at < http://www.un-documents.net/a25r2749.htm>. The principle was subsequently codified in LOSC, $\mathrm{n}$ 1, Art 137.

7 A Chircop, 'Managing Adjacency: Some Legal Aspects of the Relationship between the Extended Continental Shelf and the International Seabed Area', (2011) 42 Ocean Development and International Law 307 at 312-313; Chatham House Report, n 4, 59-63.

8 For the current state of the deep water industry and forecasts, see: Douglas-Westwood, World Deepwater Market Forecast 2016-2020 (Kent UK 2016). 
putting bidders on notice that a contingent Law of the Sea Royalty would apply in the event that the United States became a Party to the Losc. ${ }^{9}$ The position taken by the United States is that bidders require notice of the existence and contingent application of the Article 82 royalty at the stage of tendering. ${ }^{10}$

Of more substantial note at this time is Canada's practice. Canada stands out as a pioneer State because it is the first LOSC Party to issue discovery licences, which it has done with respect to developments in the deep waters off the coast of Newfoundland in the Northwest Atlantic Ocean. If economic and technical feasibility are confirmed, the licence holders will be expected to apply for production licences. The prospective issuance of the first production license will most likely occur before Canada will have defined the outer limits of its continental shelf in the Northwest Atlantic. Canada ratified the LOSC on 6 November 2003 and on 6 December 2013 made a partial submission to the Commission on the Limits of the Continental Shelf (CLCS) in accordance with Article 76 to define the outer limits of the extended continental shelf in the Northwest Atlantic. ${ }^{11}$ Under the LOsc, the Commission reviews such submissions and issues recommendations concerning the definition of the outer limit of the shelf. If Canada receives a positive recommendation, the submission will add 1.2 million square kilometres of seabed areas to national jurisdiction. Canada issued the first significant discovery licence to Norwegian company Equinor (formerly Statoil until 2018) for the Mizzen field on the Flemish Cap,

9 For example Stipulation No. 3: Law of the Sea Convention Royalty Payment in Lease Stipulations, Western Planning Area, Oil and Gas Lease Sale 233, Proposed Notice of Sale (NOS), воєм, August 2013, available at <http://www.boem.gov/ Oil-and-Gas-Energy-Program/Leasing/Regional-Leasing/Gulf-of-Mexico-Region/ Lease-Sales/233/pstips233.aspx>.

10 'If the United States becomes a party to the 1982 Law of the Sea Convention (Convention) prior to or during the life of a lease issued by the United States on a block or portion of a block located beyond the U.S. Exclusive Economic Zone (EEZ) and subject to such conditions that the Senate may impose through its constitutional role of advice and consent, then the following royalty payment lease provisions will apply to the lease so issued, consistent with Article 82 of the Convention ...' Ibid. The United States' position on the LOSC is that the bulk of it represents customary international law. However, the characterization of Article 82 as having a contingent application, i.e., if and when the US becomes a party, suggests that this particular provision might not be considered a customary rule.

11 Government of Canada, Partial Submission of Canada to the Commission on the Limits of the Continental Shelf regarding its Continental Shelf in the Atlantic Ocean: Executive Summary (Government of Canada, 2013), available at <http://www.un.org/depts/los/ clcs_new/submissions_files/can70_13/es_can_en.pdf >. The Convention entered into force for Canada on 6 December 2013, 30 days after the deposit of its instrument of ratification in accordance with LOSC, $\mathrm{n}_{1}$, Art 308(2). With this partial submission Canada managed to meet the ten-year deadline for extended continental shelf submissions in accordance with Annex II, Art (4) on the last day. 
located well beyond 200 nautical miles off Newfoundland. ${ }^{12}$ In the meantime, offshore operators have been notified that the boundaries and outer limits of licences may be reviewed after Canada establishes the outer limits of the continental shelf following recommendations from the CLCs. ${ }^{13}$

This chapter discusses the issues of implementation of Article 82 for coastal States with a special focus on Canada against the backdrop of initiatives of the Authority aimed at clarifying its role and being of assistance to LOsC State Parties. The chapter starts by discussing the Authority's initial steps to date in facilitating the implementation of Article 82 (Section 2), followed by brief analysis of textual ambiguities and uncertainties and possible interpretations in the first two paragraphs of the provision, as these constitute the core legal obligation to be implemented by Canada (Section 3). The chapter does not discuss exemptions for developing States in the third paragraph and the Authority's tasks in the fourth paragraph of Article 82. The chapter also considers issues that might arise in a hypothetical situation of production from a non-living resource straddling the shelf and the Area (Section 4). Thereafter the discussion moves to the domestic issues confronting the legal, political and economic mechanics of implementation of the provision in Canada (Section

12 'Statoil confirms up to 200M barrels at Mizzen prospect', свс News, 20 June 2012, available at <http://www.cbc.ca/news/canada/newfoundland-labrador/statoil-confirms-up -to-20om-barrels-at-mizzen-prospect-1.1251285>. In addition to the Mizzen discovery, first made in 2009, Equinor has four other discoveries in the Flemish Pass off Newfoundland: Harpoon, A light hydrocarbon discovery in 2013; Bay du Nord, a 2013 discovery estimated to hold around 300 million barrels of light high-quality oil; Bay de Verde, a light highquality oil discovery in 2016; and Baccalieu, a light high-quality oil discovery in 2016. See Equinor (Canada), available at <https://www.equinor.com/en/where-we-are/cana da.html>.

13 The following caveat was reproduced by the licensing authority for areas off Newfoundland and Labrador: 'Any sector, parcel or licence depicted on the following map, (found on pages 24 and 25), beyond 200 nautical miles off the coast of Newfoundland and Labrador is not represented by the Board to reflect the full extent of Canada's continental shelf beyond 200 nautical miles. Canada has filed a submission regarding the limits of the Outer Continental Shelf in the Atlantic Ocean with the Commission on the Limits of the Continental Shelf, the review of which is pending. Any call for bids based on a sector or parcel identified in this map and any licences issued in those areas will be subject to approval as a Fundamental Decision under applicable legislation. The boundaries of sectors, parcels or licences in areas beyond 200 nautical miles may be revised to reflect the limits of the Outer Continental Shelf established by Canada. All interest holders of production licences containing areas beyond 200 nautical miles may be required, through legislation, regulation, licence terms and conditions, or otherwise, to make payments or contributions in order for Canada to satisfy obligations under Article 82 of the United Nations Convention on the Law of the Sea.' C-NLOPB 2014-2015 Annual Report, 23, available at $<$ http://www.cnlopb.ca/pdfs/ar2015e.pdf?lbisphpreq=1 $>$. 
5). The chapter concludes with observations on the precedent-setting challenges facing Canada, as the pioneer implementing State, and the Authority in operationalizing Article 82 (Section 6).

The short and simple text of Article 82 belies the complexity of implementation. The Authority was the first to take initial steps encouraging States to consider the implementation needs of Article 82. The Authority was wellplaced to take this initiative. The Council and Assembly of the Authority are empowered by the LOsC to adopt

... rules, regulations and procedures on the equitable sharing of ... the payments and contributions made pursuant to article 82 , taking into particular consideration the interests and needs of the developing States and peoples who have not attained full independence or other self-governing status ... ${ }^{14}$

The regulatory power of the Council and Assembly is limited, and while the Authority is in a position to take steps to commence implementation of its own responsibilities in Article 82, it does not have express power to regulate the discharge of the obligation by coastal States. However, the respective obligations of the coastal State to make payments or contributions in kind and the Authority's responsibility to make arrangements to receive them are intertwined, as will be discussed below.

Using this power, in 2008 the Authority commissioned an expert study which was tabled for discussion in 2009 at a preliminary meeting of experts in Chatham House. The meeting was convened to explore and scope out legal issues of implementation and the role and tasks of the Authority. ${ }^{15}$ The meeting

\footnotetext{
14 The Council is empowered to make recommendations to the Authority to adopt rules, regulations and procedures, LOSC, n 1, Art 162(2)(o)(i). In turn, the Assembly is empowered to consider and approve them and if it does not it remands them to the Council for reconsideration in the light of the views expressed by the Assembly. Ibid, Art 16o(2)(f)(i).

15 Draft Paper for Discussion at the Chatham House/International Seabed Authority Seminar on Issues Associated with the Implementation of Article 82 of the Law of the Sea Convention, Chatham House, London, 11-13 February 2009, Fourth Draft prepared by Aldo Chircop.
} 
resulted in a ground-breaking report. ${ }^{16}$ The discourse was guided by principles and rules of the Vienna Convention on the Law of Treaties, $1969,{ }^{17}$ the context and purposes of the LOSC, and the understanding on the package deal reached at UNCLOS III, in particular the relationship between Articles 76 and 82, the relationship between the extended continental shelf and the Area, ${ }^{18}$ and the powers of the Authority stemming from Articles 82, 160 and 162. The discourse was also informed by other provisions of the LOSC, including the duty of States Parties to 'fulfil in good faith the obligations assumed under this Convention' and to 'exercise the rights, jurisdiction and freedoms recognized in this Convention in a manner which would not constitute an abuse of right.'19 The meeting report identified several issues and unanswered questions that coastal States and the Authority would need to address, including clarification of terminology, the scope of the Authority's tasks and the relationship between those coastal States and the Authority in the administration of Article 82. The report led the Assembly of the Authority to place the study of Article 82 on the formal programme of work. ${ }^{20}$ This led to the convening of a larger followup workshop of experts in Beijing in 2012, jointly convened by the Authority and the China Institute for Marine Affairs of the State Oceanic Administration of China, and resulted in a second report. ${ }^{21}$ The workshop had a practical orientation and purposed to produce draft proposals for consideration by coastal States and the Authority. ${ }^{22}$ Its conclusions and recommendations setting out

16 Chatham House Report, $\mathrm{n}$ 4. This was accompanied by a second study Non-Living Resources of the Continental Shelf beyond 200 Nautical Miles: Speculations on the Implementation of Article 82 of the United Nations Convention on the Law of the Sea, ISA Technical Study no. 5 (International Seabed Authority, 2010).

17 Convention on the Law of Treaties (adopted 23 May 1969; in force 27 January 1980), UN Doc. A/ Conf.39/27; 1155 UnTS 331 [hereinafter Vienna Convention].

18 Chatham House report, $\mathrm{n}$ 4, 12-13, 21-24.

19 LOSC, n 1, Art 300.

20 Report of the Secretary-General in International Seabed Authority, Selected Decisions and Documents of the Sixteenth Session (26 April-7 May 2010), (Kingston, 2010), para 75, available at $<$ http://www.isa.org.jm/en/documents/publications > .

21 Implementation of Article 82 of the United Nations Convention on the Law of the Sea, Report of an International Workshop convened by the International Seabed Authority in collaboration with the China Institute for Marine Affairs in Beijing, the People's Republic of China, 26-30 November 2012, ISA Technical Study no.12, at 24, available at $<$ http:// www.isa.org.jm/files/documents/EN/Pubs/TS12-web.pdf> [hereinafter Beijing Workshop Report].

22 Report of the Secretary-General of the International Seabed Authority under article 166, paragraph 4, of the United Nations Convention on the Law of the Sea, ISA Doc ISBA/19/A/2, 22 May 2013, 14-15. 
the roadmap for the next steps in implementation were submitted for consideration by the Assembly. ${ }^{23}$

The Beijing workshop produced several clarifications and recommendations pertinent to the obligation of coastal States. First, coastal States that have issued or plan to issue offshore licenses for non-living resources on the extended continental shelf were encouraged to consider and anticipate the implementation needs of Article 82. ${ }^{24}$ The report suggested that coastal States had an obligation to notify the Authority 'of the anticipated date of commercial production' which, while not an express requirement in Article 82, is a reasonable implied requirement. ${ }^{25}$ It should be recalled that the coastal State has a duty to deposit charts or lists of geographical coordinates of the outer limits of the extended continental shelf with the Secretary-General of the Authority. ${ }^{26}$ Also, the Authority needs to be in a position to receive payments and contributions in kind from the coastal State.

Second, the report noted that coastal States have the exclusive right to determine whether the obligation is to be performed through payments, i.e., monetary transfers, or contributions in kind, presumably through a portion of the resource corresponding to the required percentage. However, given the complexities of managing receipts of contributions in kind first, a problem first identified at the Chatham House meeting, the experts recommended that States be encouraged 'to make payments in the interest of simplicity and efficiency of implementation.27 It was noted that such a recommendation to States might have to be made by State Parties to the Convention.

Third, the uncertainly of the terminology of Article 82 led to the recommendation for a more detailed study of key terms as 'they are used in contemporary regulatory and industry practices across different jurisdictions. ${ }^{28}$ This is important because Article 82 was conceived as a royalty, a type of revenue generation

23 Outcomes of the International Workshop on further Consideration of the Implementation of Article 82 of the United Nations Convention on the Law of the Sea, ISA Doc ISBA/19/A/4, 6 May 2013.

24 Beijing Workshop Report, n 21, at 24: 'The ISA should encourage ocs States, in particular those that are issuing or plan to issue offshore licences for the exploitation of the non-living resources of the outer continental shelf, to consider and anticipate the implementation needs of Article 82 within their respective jurisdictions.'

25 Chatham House Report, n 4, at 51; Beijing Workshop Report, n 21, at 22-23.

26 LOSC, n 1, Art 84(2).

27 Beijing Workshop Report, $n$ 21, at 24: 'Ocs States, while enjoying the exclusive choice to make payments or contributions in kind, should be encouraged to opt only for payments in the interests of simplicity and efficiency of implementation. It is conceivable that a SPLOS resolution may be needed to move this recommendation forward.'

28 Ibid, 24. 
instrument applied to production from natural resources, long discarded in some jurisdictions, but retained by others like Canada, as will be seen below.

Fourth, given that coastal States making payments or contributions will be engaged in a long-term relationship with the Authority, the experts recommended a voluntary memorandum of understanding to help structure the relationship between the two, or a guidance document to provide practical advice in the implementation of Article 82. ${ }^{29}$ Experts preferred an informal and non-binding instrument to a formal instrument, such as an agreement between a State and an international organization.

Fifth, it was underscored that the term 'through the Authority' clearly did not mean 'to the Authority', since the function performed by the Authority is that of a receiver rather than a collector of the royalty. Clearly, the Authority needs to have a mechanism for receiving royalties and for distributing them to beneficiaries designated by the Convention. There would be issues of costs of administration of the funds that would need to be considered. Further studies and technical reports would need to be produced by the Authority. Consideration of the report at the 19th Session in 2013 anticipated continued discussions within the Authority 'to achieve a system for the pragmatic and functional implementation of article 82. ${ }^{30}$

The development of regulations for deep seabed mining in the Area occupied much of the Authority's agenda in recent years and Article 82 was largely placed on a backburner. Some Member States felt that the Authority should give priority to its work regarding activities in the Area. However, the annual reports of the Secretary-General of the Authority consistently reminded Member States of the organization's responsibilities in Article 82. At the 21st Session of the Assembly in 2015, the Beijing meeting of experts was recalled, in particular the recommendation that a study of terminological issues be undertaken and that the Secretariat hoped to progress that work in 2015, but with 'respect to the implementation of article 82, paragraph 4, of the Convention',

29 Ibid, 24: 'The ISA should explore further the concept of a Memorandum of Understanding between an ocs State and the ISA, or a guidance document, and take steps to prepare a draft for discussion, bearing in mind that such instruments will be essentially voluntary and aim to provide practical guidelines and advice to assist ocs States in the implementation of Article 82. The content should reflect terminological matters, functions and tasks, and other appropriate implementation matters discussed in this report. It could be undertaken in three sections, namely: (a) practical and administrative arrangements; (b) provisions regarding contributions in kind; and (c) considerations for ocs States to take into account.'

30 Press Release, Nineteenth Session Kingston, Jamaica 15-26 July 2013, SB/19/18, 26 July 2013, 10. 
i.e., the Authority's task in receiving and distributing benefits. ${ }^{31}$ This suggests that the Authority was under pressure to limit its work specifically to its own responsibilities in the provision and less so on those of coastal States. However, in 2015 the Authority proceeded with the recommendation of the Beijing Workshop to conduct an expert study of the terminology of Article 82 as used in the oil and gas industry on a comparative basis in order to help broaden coastal States' understanding of the issues. The study was completed in $2016 .{ }^{32}$ More recently, the Strategic Plan of the International Seabed Authority for the Period 2019-2023 adopted at the 24th Session of the Assembly includes the development of equitable sharing criteria for Article 82. ${ }^{33}$ The ISA's Finance Committee observed that the development of the criteria should be undertaken in parallel with the development of equitable sharing of financial and other economic benefits from activities in the Area to avoid duplication of work. $^{34}$

Key Terminological Issues of Concern to Coastal States

The ambiguities and gaps in Article 82 posing major challenges to implementation have been studied in the literature and addressed in the Authority's technical reports and therefore need not be recounted in detail. Some issues are purely terminological, whereas others relate to the modus operandi of implementation and are of potential concern for Canada.

\subsection{Paragraph (1)}

The paragraph (1) core rule concerning the duty of the coastal State to make payments or contributions in kind on the production from non-living resources is clear. That the choice of discharge procedure is the prerogative of the coastal

31 Report of the Secretary-General of the International Seabed Authority under article 166, paragraph 4, of the United Nations Convention on the Law of the Sea, ISA Doc ISBA/21/A/2, 3 June 2015, 3 .

32 A Study of Key Terms in Article 82 of the United Nations Convention on the Law of the Sea, ISA Technical Study No. 15, authored by W Spicer/E McIsaac, (Kingston, Jamaica: International Seabed Authority, 2016). The study focused on the use of key terms in the following jurisdictions, according to whether their revenue generation systems are based on royalty or taxation regimes: (a) royalty regimes: Australia; Brazil; Canada (Alberta; Newfoundland and Labrador); Nigeria; and United States; taxation regimes: Norway; Russian Federation; and United Kingdom [hereinafter Key Terms Report].

33 Decision of the Assembly of the International Seabed Authority relating to the strategic plan of the Authority for the period 2019-2023, ISBA/24/A/10 (27 July 2018), para 21.

Report of the Finance Committee, ISBA/24/A/6 - ISBA/24/C/19 (13 July 2018), para 27. 
State is also clear. The term 'contribution in kind' could give rise to alternative meanings. The question that arises is whether this term is meant to refer to a share of the resources or potentially, and more broadly to other contributions of equivalent value, such as technical assistance, technology transfer, and so on. ${ }^{35} \mathrm{~A}$ recent paper revived an earlier idea by this author that a contribution in kind could be interpreted to include national official development assistance. ${ }^{36}$ The deliberations at UNCLOS III suggest that negotiators may have had in mind a share of the resource, because at the time developing States wanted to ensure they had access to oil production. The Beijing Workshop appeared to lean towards an interpretation in favour of a share of the resource. ${ }^{37}$

Assuming an actual share of the natural resource is the correct legal interpretation of contribution in kind, a related legal, administrative and economic issue would arise, namely where and when does the Authority take delivery of the produced resource and who is responsible for the delivery and costs (e.g., transportation, brokerage, insurance, etc.)? The Authority is not equipped with the tools and capacities necessary to handle these administrative tasks. It is not mandated to raise the funds needed for this purpose and nor is it authorised to levy an overhead charge or fee. ${ }^{38}$ The obligation of coastal States does not expressly extend to anything more than making the contribution in kind. In any case, if coastal States act on the advice of the Chatham House and Beijing Workshop reports that payments are easier, more efficient and less costly to administer, then the vagueness and complexities of in kind contributions would be avoided altogether.

\section{2 $\quad$ Paragraph (2)}

The major difficulties for coastal State implementation are mostly with regard to paragraph 2 . The general rule in paragraph 2 is that payments

35 Chatham House Report, n 4, 51-52.

36 W Spicer, 'Canada, the Law of the Sea Treaty and International Payments: Where Will the Money Come From?' spp Research Papers vol 8(31) (University of Calgary, 2015), 20.

37 Beijing Workshop Report, n 21, at 20: 'When negotiated at the Third United Nations Conference on the Law of the Sea, 1973-1982 (UNCLOS III), the intention behind insertion of contributions in kind was to secure resource access to State Party beneficiaries.' Also ibid at 22: 'The difficulties to be encountered when an ocs State opts to make 'contributions in kind' have already been addressed in this report. In addition to those difficulties, an understanding of what is acceptable as a contribution in kind within the letter and spirit of the provision is necessary. Discussions in the Working Group proceeded on the assumption that this phrase refers to a share of the resource, but other possible interpretations were not discussed.'

38 Chatham House Report, n 4, 37-38; Beijing Workshop Report, n 21, at 23 in relation to contributions in kind, and suggesting a further study. 
and contributions are to be made annually, subject to a grace period, i.e., a royalty-free period during the first five years of production, to enable recovery of expenses incurred in bringing the resource to production. On the sixth year of production, a royalty of one percent applies and will increase by one percent annually until seven percent is reached on the thirteenth year, and which will remain the royalty's ceiling thereafter. The principles behind the royalty are clear.

Clarity diminishes on a closer look at the details. For example, can the grace period be interrupted if production is suspended and reactivated on resumption of production? ${ }^{39}$ Presumably yes, as a matter of fairness, but this is a matter of interpretation of text which is not directly on point. What is the meaning of 'annually'? Financial years vary by jurisdiction. ${ }^{40}$ It could refer to the financial year in the jurisdiction concerned or to the anniversary date of first production, and if production is suspended the calculation of the year may have to vary accordingly.

A difficult term is 'all production'. During negotiations this term appears to have meant gross production, less any portion of the resource used to enhance production according to Article 82(2) (e.g., use of the resource for production of energy for operations, re-injection of gas into a well to enhance production, flaring for safety purposes, etc.). ${ }^{41}$ The meaning of all production as gross production was intentional because this approach simplified the royalty and was a common practice in those jurisdictions deriving royalty-based revenues in the oil and gas industry. The alternative interpretation of calculating the royalty on the basis of net production would have engaged a complex discussion of accounting practices that varied significantly among jurisdictions. ${ }^{42}$ In the contemporary context of deep water drilling and production, where costs are significantly higher than offshore production elsewhere, an additional levy to the applicable royalty or tax regime under national law could impact on the feasibility of the entire operation. However, this is a domestic concern and it does not excuse or lessen the international legal obligation. ${ }^{43}$

39 Chatham House Report, n 4, 56-57.

40 Ibid, 32.

41 Chircop \& Marchand, n 4, 297-298; International Law Association, Committee on the Outer Continental Shelf, 'Report on Article 82 of the UN Convention on the Law of the Sea (UNCLOS),' Rio De Janeiro Conference, 2008, para 2.8, available at <http://www.ila -hq.org/en/committees/index.cfm/cid/33>. Nations Conference on the Law of the Sea (Honolulu: Law of the Sea Institute, 1983), 98-99.

43 Vienna Convention, $n$ 17, Art 27: 'A party may not invoke the provisions of its internal law as justification for its failure to perform a treaty.' 
The next set of issues in the second paragraph concern the meaning of 'value or volume of production at the site.' Is the value expected to be determined at the well-head or at the market location at the time the product is sold? ${ }^{44}$ There are significant differences between oil and gas because they are transported and priced differently. While oil may be priced at the well-head, gas tends to be priced at the point of distribution, which may be at the terminal point of a pipeline. The reference to 'site' adds another layer of ambiguity as it could be interpreted to mean 'resource field, geological structure, well site, license area and a whole development area subject to multiple licenses' ${ }^{45}$ Some deposits may be layered over each other in the same field.

Negotiated through four successive versions of early drafts of the future LOSC, ${ }^{46}$ Article 82 was drafted on the basis of information, assumptions and an understanding of the petroleum industry and government revenue generation practices of the 1970s. A key assumption was that the first five years constituted the period for the recovery of developmental costs. ${ }^{47}$ Today, deep water drilling (on extended continental shelves as compared to shallow inshore waters) and cost models are riskier and fundamentally different, such that the period of cost recovery may be significantly longer than the Article 82 grace period. ${ }^{48}$ Article 82 follows a royalty model. ${ }^{49}$ The concept of royalty meant essentially a share of the produced resource to reflect a rent payable to the owner of the resource. Today government revenue generation in this industry also includes a range of fiscal tools such as corporate income tax, profit taxes, resource rent taxes, value-added taxes, excise taxes, etc. ${ }^{50}$ Revenue generation practices have

44 Chatham House Report, n 4; 33-34; Beijing Workshop Report, n 21, $20-21$.

45 Beijing Workshop Report, n 21, 21-22. The meaning of site was also discussed at the Chatham House Workshop. Chatham House Report, n 4, 61-63.

46 The earlier iterations of Article 82 were contained in the following drafts: ISNT, 1975, Art 69; RSNT, 1976, Art 70; ICNT, 1977, Art 82. The final text remained largely unchanged in the following drafts: ICNT Rev 1, 1977; ICNT Rev 2, 1980; Draft Convention (Informal Text), 1980; and the Draft Convention, 1981, which was the last version of the text before the LOSC was adopted in 1982. Chatham House Report, n 4, 19-20.

$47 \quad$ Nordquist \& Park, n 42.

48 'Deep water drilling and production involves long-term, multi-billion dollar projects that take several years to complete and are less impacted by short-term fluctuations in oil prices. Offshore operators often have major project budgets for years and most projects are completed with the anticipation of higher oil prices in the future.' US Energy Information Administration, Trends in U.S. Oil and Natural Gas Upstream Costs, March 2016, at 23 $<$ https://www.eia.gov/analysis/studies/drilling/pdf/upstream.pdf>.

49 Chircop \& Marchand, $n 4$.

50 EM Sunley, T Baunsgaard and D Simard, 'Revenue from the Oil and Gas Sector: Issues and Country Experience,' (World Bank, 2002), 2, available at <http://siteresources.worldbank .org/INTTPA/Resources/SunleyPaper.pdf >; J Mintz and D Chen, Capturing Economic 
made fundamental shifts, with some jurisdictions moving away from royaltybased levies in favour of taxation-based regimes, such as major petroleum producing States Norway and the United Kingdom. ${ }^{51}$ Revenue is thus generated in more complex ways than, or instead of, royalties. Others, like Canada and the United States, have retained royalties side-by-side other fiscal tools. ${ }^{52}$ Naturally, Article 82 is a levy on the production of the resource and not on the entirety of the revenue generated by the operation. This is important to note as the producer may significantly enhance the original product to produce by-products. Even so, for those jurisdictions where royalties are no longer levied, there is concern regarding how the payments to be made through the Authority are to be generated. Thankfully, the latter is not a Canadian problem, but Canada has other, perhaps more complex domestic issues to navigate.

\section{$4 \quad$ Production from Resources Straddling the Outer Limits}

The LOSC does not require a coastal State to refrain from activities on the extended continental shelf until the process of definition of the outer limits pursuant to Article 76 has been completed. The precise limits of the international seabed area will remain uncertain until outer limits of extended continental shelves are fully defined in accordance with the requirements of Article 76 . The LosC requires coastal States to give due publicity to charts or lists of geographical coordinates of the outer limit lines of the continental shelf and to deposit a copy of such charts or lists with the Authority's Secretary-General. ${ }^{53}$ At the time of writing, there appears to be a low rate of compliance by coastal States that have received recommendations from the Commission regarding their submissions on the outer limits. By 2015 only Australia, Ireland, Mexico, Niue and Philippines had deposited charts or lists with the Secretary-General. ${ }^{54}$

Rents from Resources through Royalties and Taxes, sPP Research Papers vol 5 (University of Calgary, 2012), 5 .

$5^{1} \quad$ Key Terms Report, $\mathrm{n}^{2}$.

$52 \quad$ Ibid.

53 Losc, $\mathrm{n} \mathrm{1}$, Art 84(2). This duty is in addition to the Art $76(9)$ duty of a State to deposit charts, lists and other relevant information regarding the outer limits of the continental shelf with the UN Secretary-General.

54 Report of the Secretary-General of the International Seabed Authority under article 166, paragraph 4, of the United Nations Convention on the Law of the Sea, ISA Doc ISBA/21/A/2, 3 June 2015, 2-3. 
The Secretary-General renewed calls for States to submit charts or lists of coordinates in his most recent annual report. ${ }^{55}$

The definition of the outer limits in a final and binding manner, on the basis of recommendations from the Commission, has the benefit of legitimizing the boundary between the extended continental shelf and the Area. This is important for the offshore oil and gas industry because it provides greater certainty regarding the legality of their licenses. The occurrence of single geological structures straddling international maritime boundaries is a realistic possibility, as demonstrated by the several instances of offshore joint development and unitization activities around the world. ${ }^{56}$ Where a deposit is known to straddle a licence area or maritime boundary, a longstanding good oilfield practice is for the development of the resource to be unitized, that is developed in an integrated manner. ${ }^{57}$ Licence holders would then come to agreement on their respective shares of production and a model agreement will be developed for this purpose. ${ }^{58}$

If such a situation were to arise, for example where a commercial hydrocarbon find straddles areas within and beyond national jurisdiction, there could be three issues to consider. First, there would need to be consideration of whether the resource should be developed on the basis of a joint development zone or, alternatively, by being unitized through the direct involvement of the licence holders. In either case, there would need to be approval by the Authority insofar as licence holders in the Area are concerned. The Authority would likely need to develop regulations for this purpose, as it has for other mineral resources. The Authority has an international governance structure for licencing activities in the Area governed by Part XI of LOSC, and is overseen by Member States, who are also State Parties and include the coastal State concerned. In turn, the coastal State could have sub-national units it would need to involve in negotiations. Canada, a federal State, is a good example of

55 Report of the Secretary-General of the International Seabed Authority under article 166, paragraph 4, of the United Nations Convention on the Law of the Sea, ISBA/24/A/2 (29 May 2018), para 8.

56 J Lang Weaver and DF Asmus, 'Unitizing Oil and Gas Fields around the World: A Comparative Analysis of National Laws and Private Contracts,' (2006) 28 Houston Journal of International Law 4. See also DM Ong, 'Joint Development of Common Offshore Oil and Gas Deposits: “Mere” State Practice or Customary International Law?', 93 American Journal of International Law 771.

57 JC Woodliffe, 'International Unitization of an Offshore Gas Field,' (1977) 26 International and Comparative Law Quarterly 338.

$5^{8}$ Lang Weaver \& Asmus, n 52, 22 et seq. For the model agreement, see Association of International Petroleum Negotiators, available at <www.aipn.org/modelagreements/>. 
this because the regulation of the offshore is conducted by federal-provincial boards. ${ }^{59} \mathrm{~A}$ consequence of a joint development zone or unitization scenario is the need for regulators on both sides of the boundary to revisit the licences in the areas adjacent to the boundary and to explore whether production policies and regulatory approaches require adjustment. Moreover, environment protection standards may differ and would need to be reconciled for the operation in question.

Second, the payments or contributions in kind to be made by the coastal State would logically apply to only a portion of the produced resource. If the resource is unitized, the production units will be located in a manner to optimize production and it is conceivable that most of these might be placed on one side of the boundary, rather than be evenly distributed on the shelf and in the Area. The consequence is that the meaning of 'site' might not be clear where most, if not all of the production units are placed in the Area, for the purpose of determining the Article 82 eligible production.

Third, Article 142 of LOSC safeguards the rights of the coastal State by providing that ' $[\mathrm{A}]$ ctivities in the Area, with respect to resource deposits in the Area which lie across the limits of national jurisdiction, shall be conducted with due regard to the rights and legitimate interests of any coastal State across whose jurisdiction such deposits lie. ${ }^{60}$ The duty in the Convention is not reciprocal (and the Authority does not enjoy a counterpart right of protection), but this author is of the view that there might be a duty concerning transboundary resources at customary international law which could apply to the unilateral actions of the coastal State, such as the duty to inform, consult and invite to cooperate. ${ }^{61}$ Accordingly, although the Authority would be expected to consult the coastal State with regard to activities in the Area, an analogous duty could be expected for the coastal State on the basis of general international law. From the coastal State's perspective, the type of activity in the Area adjacent to the boundary that could give rise to concern is where operations pose a threat to the marine environment and resources of the EEZ or possibly even to the sedentary species of the continental shelf. From the Authority's perspective, perhaps the major concern is where the coastal State issues licences for unilateral production from a transboundary resource.

\footnotetext{
59 Spicer, $\mathrm{n}_{36}$.

6o LOSC, n 1, Art 142(1).

61 Suriname/Guyana Arbitration, Permanent Court of Arbitration (Award), 17 September 2007, available at <www.pca-cpa.org/ showpage.asp?pag_id=1147 $>$.
} 
Although Canada ratified the LOSC in 2003, it was unprepared for the implementation of Article 82. This is ironic because during UNCLOS III Canada played an active role in the negotiation of the provision, both as a margineer State seeking national gain while at the same time exploring options for a potential compromise. In 1975, Secretary of State for External Affairs Allan J MacEachen stated Canada's commitment to revenue-sharing. ${ }^{62}$ This position was pursued consistently by the Canadian Delegation led by Ambassador Alan Beesley, which joined ranks with the United States' and other delegations in exploring options for a compromise through the establishment of a revenuesharing scheme primarily for the benefit of developing countries, in exchange for agreement on Article $76 .^{63}$ Negotiations were difficult and Canada, like other delegations, had to compromise. In 1979 Ambassador Beesley underscored that revenue-sharing must be respectful of the coastal State's sovereign rights over the resources of the continental shelf and must not be set at a level which is unreasonable, considering the high costs of deep water activities. ${ }^{64}$ In 1980, when compromise was not yet fully reached in the late hours of UNCLOS III, Ambassador Beesley reiterated that position and was critical of the raising of the royalty ceiling from five percent to seven percent. He therefore reserved his delegation's position '... not out of lack of generosity but because the suggested rate could make it uneconomic for Canada to explore and exploit its continental margin in deep, cold water areas unless some safeguard provision was developed to ensure that any revenue-sharing we could agree upon would be practicable.' The Canadian Delegation's position was that Canada '... was prepared to explore the possibility of financial contributions related to the net revenues derived from the resources of the continental shelf beyond 200 miles from shore.' ${ }^{65}$ However, '... the question of revenue-sharing will require further discussion with a view to ensuring that the formula and the rate of contribution

62 Secretary of State MacEachen stated that '... we are prepared to explore the possibility of financial contributions related to the net revenues derived from the resources of the continental shelf between 200 miles from the shore and the seaward edge of the continental margin. We are prepared to explore that possibility and we are prepared to support that principle in order to promote an accommodation.' Statement by the Delegation of Canada, 2 April 1980, Doc A/CONF.62/WS/4, 10 April 1980, in Third United Nations Conference on the Law of the Sea: Official Records, 9th Session, 3 March-4 April 1980 (United Nations, 1981), 101 at 102.

63 Ibid.

64 Ibid, 102.

65 Ibid, Plenary, 125th meeting, 2 April 1980, at 8. 
will be both equitable and viable from the standpoint of both potential contributors and beneficiaries ... ${ }^{66}$ On the eve of the vote on the final package of the LOSC in 1982, Secretary of State MacEachen stated that '[W]e must recognize, however, that there will be funds to dispense only if these resources prove to be commercially exploitable. ${ }^{67}$ This was a difficult compromise for the margineers, because other delegations were of the view that the royalty rate was not proportionate to the margineers' continental margin gains.

The difficulties Canada faced in negotiating Article 82 were only the beginning of a series of implementation challenges at the domestic level. According to the Constitution of Canada, a province's boundaries may not be changed without its consent ${ }^{68}$ and that all lands, resources and royalties in provincial territory at the time of Union belonged to the province. ${ }^{69}$ With the growing interest in offshore development, the question arose as to whether the boundaries of coastal provinces included adjacent ocean space. Complicating this question was that the various provinces joined confederation at different dates, raising an additional issue with regard to their entitlements under international law at the time to determine what they imported into and when they joined the Union. ${ }^{70} \mathrm{~A}$ case by cases analysis was essential. In 1967 the Supreme Court of Canada determined that the territorial sea, its seabed and subsoil off British Columbia (Vancouver Island) belonged to Canada, not the province. ${ }^{71}$ In 1984 the waters in Juan de Fuca Strait and Strait of Georgia between Vancouver Island and the British Columbia mainland were determined to be

66 Ibid, 9th Session, at 102.

67 Third United Nations Conference on the Law of the Sea: Official Records, Resumed 11th Session, 185th meeting, 6 December 1982 (United Nations, 1982).

68 Constitution Act, 1867, 30 \& 31 Victoria, c 3 (UK), s 43: 'An amendment to the Constitution of Canada in relation to any provision that applies to one or more, but not all, provinces, including (a) any alteration to boundaries between provinces, ... may be made by proclamation issued by the Governor General under the Great Seal of Canada only where so authorized by resolutions of the Senate and House of Commons and of the legislative assembly of each province to which the amendment applies.'

69 Ibid, s 109: 'All Lands, Mines, Minerals and Royalties belonging to the several Provinces of Canada, Nova Scotia, and New Brunswick at the Union, and all Sums then due or payable for such Lands, Mines, Minerals, or Royalties, shall belong to the several Provinces of Ontario, Quebec, Nova Scotia, and New Brunswick in which the same are situate or arise, subject to any Trusts existing in respect thereof, and to any Interest other than that of the Province in the same.'

70 For example while Nova Scotia was a founding province of Confederation on 1 July 1867, British Columbia joined confederation on 20 July 1871 and Newfoundland on 31 March 1949. Newfoundland became Newfoundland and Labrador after a constitutional amendment in 2001.

71 Reference Re Ownership of Off Shore Mineral Rights [1967] SCR 792. 
encompassed within the limits of British Columbia when it joined the Union in 1871 and were consequently provincial. ${ }^{72}$

Newfoundland (Newfoundland and Labrador since 2001) was the last province to join Canada, in 1949. This is significant because the province joined the Union shortly after the Truman Proclamation on the Continental Shelf of 1945. It will be recalled that the Proclamation triggered the development of pertinent general international law to the effect that 'the continental shelf may be regarded as an extension of the land-mass of the coastal nation and thus naturally appurtenant to it' and with the consequence that 'the natural resources of the subsoil and sea bed of the continental shelf beneath the high seas but contiguous to the coasts of the United States as appertaining to the United States, subject to its jurisdiction and control. ${ }^{73}$ In a few years this concept attained the status of customary international law so that the rights of the coastal State over the continental shelf belonged to that State ipso facto, ipso iure and ab initio, that they were exclusive to it and that its title did not depend on express claim, occupation or use. ${ }^{74}$ Newfoundland was of the view that it joined Canada while possessing the territorial and other rights at international law appertaining to a State, and that these included the territorial sea and continental shelf. In 1983 a Newfoundland Court of Appeal decision found that the province had a territorial sea of three nautical miles when it joined the Union. ${ }^{75}$ Continental shelf rights remained uncertain. A year later, the Supreme Court of Canada decided that Newfoundland had not acquired continental shelf rights prior to joining the Union in $1949 .{ }^{76}$ The reasons were that continental shelf rights granted by international law to a coastal State are not in pith and substance proprietary, but are rather 'an extraterritorial manifestation of external sovereignty.77 In 1949 Newfoundland did not enjoy external sovereignty as this power and right were enjoyed by the Crown in right of the United Kingdom. The Supreme Court went on to hold that if Newfoundland

72 Reference Re Ownership of the Bed of the Strait of Georgia and Related Areas, [1984] 1 SCR 388 .

73 Policy of the United States With Respect to the Natural Resources of the Subsoil and Sea Bed of the Continental Shelf, 150 - Proclamation 2667-28 September 1945.

74 North Sea Continental Shelf, Judgment, ICJ Reports 1969, 3 at para 19. For a commentary on how the continental shelf doctrine attained the status of customary international law, see ZJ Slouka, International Custom and the Continental Shelf: A Study in the Dynamics of the Customary Rules of International Law (Martinus Nijhoff, 1968).

75 Reference Re Mineral and other Natural Resources of the Continental Shelf (1983), 145 DLR (3d) 9 (Nfld CA).

76 Reference Re the Seabed and Subsoil of the Continental Shelf Offshore Newfoundland, [1984] 1 SCR 86.

Ibid. 
had acquired continental shelf rights prior to joining Canada, the Terms of Union perpetuating natural resource rights in the Province at the date of Union did not extend to continental shelf rights. Moreover, the Court went on to hold that international law did not confer continental shelf rights in 1949 and that such rights 'were not indisputably recognized before the Geneva Convention of 1958', and while coastal States enjoyed these rights retroactively, they 'do not have a retroactive effect capable of assisting Newfoundland. ${ }^{78}$

The Supreme Court's decision did not sit well with the Province. While the legal basis of the dispute appeared to have been resolved by the Supreme Court, the issue of rights to the shelf's resources continued as a major political problem. During judicial proceedings, other provinces, including neighbouring Nova Scotia, adjacent to which is a large extended continental shelf, intervened to advocate in favour of provincial rights. The differences between Newfoundland and Labrador and the federal government were finally resolved in a political settlement that was mirrored in federal and provincial legislation in 1987 and $1990 .{ }^{79}$ The federal government agreed that the regulation of offshore activities would occur through federal-provincial boards. Canada agreed that the royalties from offshore production would be levied by the federal government and equal amounts would be paid to the provinces, as if production occurred in the provinces. ${ }^{80}$ The consequence of this legal fiction is that the Province of Newfoundland and Labrador legislated the levying of royalties and which it retains. ${ }^{81}$

Somehow Article 82 did not feature in the history of the federal-provincial disputes, with the consequence that the political and legal settlements omitted reference to the potential role of the LOSC provision. Several rounds of calls to bid were issued as a matter of course with no mention of the royalty applying to licence areas outside 200 nautical miles. ${ }^{82}$ The 2012 Mizzen discovery on

78 Ibid.

79 Canada-Newfoundland and Labrador Atlantic Accord Implementation Act, SC 1987, c 3; Canada-Newfoundland and Labrador Atlantic Accord Implementation Act, RSNL 1990, c C-2. There was a similar settlement with Nova Scotia: Canada-Nova Scotia Offshore Petroleum Resources Accord Implementation Act, SC 1988, c 28; Canada-Nova Scotia Offshore Petroleum Resources Accord Implementation (Nova Scotia) Act, 1987 c 3.

8o The responsible federal government department is Natural Resources Canada. See Natural Resources Canada, 2014-2015 Departmental Performance Report (Canada, 2015), 57, available at <http://www.nrcan.gc.ca/sites/www.nrcan.gc.ca/files/performancereports/files/ dpr-2014-15/NRCan-DPR2014-15_e.pdf>.

81 Petroleum and Natural Gas Act, RSNL 1990, c P-10.

82 Early licences on the extended continental shelf are discussed by Chircop and Marchand, n 4 , at 281 . 
the extended continental shelf off Newfoundland and Labrador was on the basis of a licence issued by the Canada-Newfoundland \& Labrador Offshore Petroleum Board and without including any reference to the Article 82 royalty.

The significance of Article 82 in Canada was flagged early in the scholarly literature. ${ }^{83}$ It was observed that Canada could face difficulties in the implementation of the provision, not only due to the uncertainty of the terminology in the provision, but also, and most especially, because of the political understanding reached between the federal and provincial governments with respect to the offshore royalty regime. The oil and gas industry enters into agreements for prospecting, exploration, development and production, in response to original calls to tender, and production agreements would be expected to subsist for decades.

The first federal official notice of the potential application of Article 82 with regard to licenses on the extended continental shelf in the Northwest Atlantic was made only in 2013, ${ }^{84}$ likely as a result of the Beijing Workshop of experts and the recommendation to the Authority to call upon State Parties to consider taking steps for implementation. ${ }^{85}$ While differences between the federal and Newfoundland and Labrador governments remained behind closed doors for much of the time until then, they are now out in the open, in dispute and with no solution announced, or in sight. ${ }^{86}$ The federal position is that the Article 82 royalty should be levied from royalties on production, which at this time are enjoyed exclusively by the province. ${ }^{87}$ Newfoundland and Labrador considers this as Canada's obligation. ${ }^{88}$ Natural Resources Canada, the federal government organization primarily responsible with regard to royalty management, has made the issue an object of focused study. Its plans and priorities

83 A Chircop and B Marchand, 'Oceans Act: Uncharted Seas for Offshore Development in Atlantic Canada?' (2001) 24 Dalhousie Law Journal 23 at 30-32.

84 'The Board [Canada-Newfoundland \& Labrador Offshore Petroleum Board] informs prospective bidders for these parcels, which are entirely or partially beyond Canada's 200 nautical mile zone, that it has been advised by the Government of Canada that, in order to meet obligations arising pursuant to article 82 of the United Nations Convention on the Law of the Sea, additional terms and conditions may be applied through legislation, regulations, amendments to licences or otherwise.' Call for Bids No. NL13-01 (Area ' $\mathrm{C}$ ' Flemish Pass), The Newfoundland and Labrador Gazette, vol 88(23), 7 June 2013, at 213.

85 Beijing Workshop Report, $\mathrm{n}$ 21, 24.

86 'Ottawa, N.L. unsure who will pay UN tax on new oil finds', CBC News, 28 October 2013, available at <http://www.cbc.ca/news/canada/newfoundland-labrador/ottawa-n-l -unsure-who-will-pay-un-tax-on-new-oil-finds-1.2251838>.

$87 \quad$ Ibid.

88 Ibid. 
for 2015-2016 included 'developing a domestic mechanism to implement Article 82 of the United Nations Convention on the Law of the Sea. ${ }^{89}$ However, the current 2018-2019 departmental plan makes no mention of continuing work on Article 82. ${ }^{90}$ Deliberations on a solution appear to be on hold, possibly because production on the extended continental shelf is not imminent.

The performance of Article 82 as a treaty obligation is clearly Canada's responsibility as a State in international law, and this is confirmed in the country's constitutional law. ${ }^{91}$ As observed earlier, domestic law issues that impede implementation may not be invoked to avoid the international obligation. ${ }^{92}$ Thus the onus to develop a solution lies with the federal government. The federal government is bound by a political accord and related legislation concluded three decades ago. The domestic solution would have to be more than a simple amendment of pertinent federal and provincial legislation. Canada may well have to explore a political solution first, followed by legislative steps, perhaps not dissimilar to the political settlement concluded in the wake of the Supreme Court of Canada Reference that rendered a decision unpalatable to Newfoundland. In that settlement the federal government was generous and relinquished royalty receipts to the province, thus enabling the offshore industry in the Northwest Atlantic to be launched. This renewed scenario means the federal government would bear the principal responsibility for Article 82. This route could provoke negative reactions from other provinces, in particular oilproducing provinces, because it could be perceived as a subsidy for provincial production of offshore oil and gas that is not similarly enjoyed by land-based producers.

If the federal government insists on clawing back domestic royalties currently levied by Newfoundland and Labrador or by introducing a surcharge royalty or levy on current operators, it is possible additional issues could arise. In addition to increasing uncertainty in the Atlantic offshore industry at a time when revenues are low because of low oil prices, there could be the realistic prospect of prolonged federal-provincial litigation. In respect to the latter,

89 Natural Resources Canada, Reports on Plans and Priorities, 2015-2016, Strategic Outcome 1, Sub-Program 1.1.3: Energy Market Regulation and Information, available at <http:// www.nrcan.gc.ca/plans-performance-reports/rpp/2015-16/17006>.

9o Natural Resources Canada, 2018-19 Departmental Plan, available at <https://www.nrcan .gc.ca/sites/www.nrcan.gc.ca/files/plansperformancereports/dpr/2018-19-DP-NRCan -EN.pdf>.

91 Constitution Act, n 68, s 132.

92 Vienna Convention, $\mathrm{n}$ 17, Art 27. 
operators would be faced with an additional expense that could weigh on the commercial viability of expensive operations in the deep waters of the extended continental shelf, essentially recalling Secretary of State McEachen's warning about the challenges of Article 82 .

It is possible that in the larger scheme, the Article 82 levy, applied over and above existing royalties, might not be perceived as a major issue by the first industry movers on the Atlantic extended continental self. In the alternative, i.e., if it were to become an issue, a practical way forward could be to distinguish between pre-2013 and post-2013 calls to bid licensees. Tenderers to the latter call received notice of Article 82 and can be considered as forewarned, ${ }^{93}$ as have subsequent responders to subsequent calls for bids, most recently in $2016 .{ }^{94}$ They would be in a position to anticipate future production cost scenarios against the backdrop of domestic and Article 82 royalties. Pre-2013 calls to bid licensees could be addressed differently because they were not put on notice at the time they placed their bids. The federal government would either absorb the cost or enter into discussions with Newfoundland and Labrador to explore a cost-sharing arrangement. However, the latter is not likely politically and economically realistic because the economy of Newfoundland and Labrador has consistently had the highest unemployment levels in the country and its heavy reliance on single resource industries, initially fisheries and more recently oil, makes it especially vulnerable to external market and environmental factors.

Article 82 poses implementation challenges for both coastal States and the International Seabed Authority. This chapter has discussed the challenges faced by coastal States, with a particular focus on Canada. Although offshore exploration licences have been issued by a few States, Canada appears to be the first LOSC Party to issue significant discovery licences for areas on the extended continental shelf. While Canada has taken domestic steps to study how domestic implementation will affect the internal royalty arrangements, it will need to address the political and economic impacts in a fair and practical

93 Call for Bids No. NL13-01, n 84.

94 The most recent call repeated the notice in the 2013 call almost verbatim. See 'C-NLOPB Announces 2016 Calls for Bids,' 2 April 2016, available at <http://www.cnlopb.ca/news/ nr20150331.php>. 
manner, and to do so in the near future to ensure that there will be a smooth transition from discovery to production licences.

Being first entails a special responsibility for Canada. It places Canada in a leadership role and implies a responsibility to establish a good implementation precedent. The precedent has two dimensions. First, the construction of key terms in the first two paragraphs of Article 82 is a matter 'concerning the interpretation or application' of LOSC, and while the coastal State may develop a particular interpretation, it has to be reasonable and acceptable to other LOSC State Parties, in other words it reflects the quid pro quo of Articles 76 and 82. Second, the first State to implement Article 82 will need also to develop a good working relationship with the Authority, because that State and the Authority will be engaged in a long-term relationship. 